\title{
INFLUENCE OF ECOLOGICAL FACTORS ON THE PATTERNS OF FISH SPECIES RICHNESS IN TROPICAL INDIAN RIVERS
}

\author{
Manas K. DAS ${ }^{1 *}$, Malay NASKAR ${ }^{1}$, Mohammad L. MONDAL ${ }^{2}$, Pankaj K. SRIVASTAVA ${ }^{1}$, \\ Sumanta DEY ${ }^{3}$, and Anirban REJ ${ }^{1}$ \\ ${ }^{1}$ Central Inland Fisheries Research Institute (ICAR), Barrackpore, Kolkata, India \\ 2 Planning Department, Delhi Secretariat, Delhi, India \\ ${ }^{3}$ Department of Fisheries, Government of West Bengal, India
}

Das M.K., Naskar M., Mondal M.L., Srivastava P. K., Dey S., Rej A. 2012. Influence of ecological factors on the patterns of fish species richness in tropical Indian rivers. Acta Ichthyol. Piscat. 42 (1): 47-58.

\begin{abstract}
Background. Rivers in India harbouring a rich diversity of fish are at present subjected to intense anthropogenic stress leading to degradation of the habitat. An understanding of the complex ecological variables determining species richness in these rivers is lacking. The relation between the ecological parameters (climate, hydrology, and morphometry) and the fish species richness were assessed in fourteen major rivers of India.

Materials and methods. The data of seven ecological variables of fourteen major rivers of India for the years 1994-2009 were quantitatively analysed for determining their influence on fish species richness. Principal factor analysis (PFA) was carried out for dimension reduction and eliminating collinearity. Subsequently, fish richness was regressed on the retained factors under generalised linear model (GLM) for determining contribution of factors towards species richness in rivers.

Results. The most influential determinants of species richness were the factors such as: surface area of the river basin (0.439) followed by fish habitat availability potential (0.326) a synthesis of the variables rainfall, discharge and sediment load. The predicted loss of fish species is evident at a $10 \%$ alteration in the ecological variables of the rivers.

Conclusion. The predicted loss of fish species richness is indicated at a10\% alteration of the habitat factors in most of the rivers and can be useful for river planners and conservationists.
\end{abstract}

Keywords: fish species richness, tropical Indian rivers, ecological factors

\section{INTRODUCTION}

India is endowed with a rich and diverse riverine resource of 14 major rivers viz. Ganga, Brahmaputra, Brahmani, Cauvery, Godavari, Indus, Krishna, Mahanadi, Mahi, Narmada, Periyar, Sabarmati, Subarnarekha, and Tapti covering $83 \%$ of the drainage basin and accounting for $85 \%$ of the surface flow (Anonymous 2004).

The rivers in India harbour one of the richest fish genetic resources in the world (Vass et al. 2009). The present checklist of primary freshwater fishes (Devi and Indra 2012) lists 667 species. The population of the main groups is $62 \%$ cyprinoids, $26 \%$ siluroids, and $12 \%$ of other groups. The species have been assigned to 12 orders, 35 families, and 149 genera. Many of these species are common to the Indian river system. The commercially important fish species groups in the colder stretch of the rivers are the snow trout, rainbow trout, schizothoracids, and a few carp species. In the warm waters the Indian major carps and other cyprinids, catfishes, air-breathing and feather-back fish species constitute an important fishery.

Unfortunately, over the last few decades the riverine ecosystems have been subjected to intense anthropogenic pressure resulting in its degradation and habitat loss for the fishes. As a consequence, many riverine fish species have become highly endangered (Sarkar et al. 2009). The concern for the habitat degradation in India has at present been compounded by the impact of climate change on these aquatic ecosystems (Vass et al. 2009).

Fish species diversity pattern in rivers is dependent on the complex interaction of the different ecological variables of the river viz., size, surface area of the drainage basin, mean annual river discharge, temperature, depth, flow velocity, channel morphology, substrate, and climate (Welcomme 1985, Hugueny 1989, Oberdorff et al. 1995, 1997, Pusey and Kennard 1996, Guégan et al. 1998, Bunn and Arthington 2002, Arrington and Winemiller 2003, Postel and Richter 2003, Poff and Zimmerman 2010). Biological

\footnotetext{
${ }^{*}$ Correspondence: Dr. M.K. Das, Head and Principal Scientist, Fishery Resource and Environmental Management Division, Central Inland Fisheries Research Institute,
} Barrackpore, Kolkata - 700 120, India, phone: 91-3325452061, fax: 91-3325452061, e-mail: mkdas412@rediffmail.com. 
factors like food, competition, and predation also have a critical influence in determining the fish diversity pattern in rivers (Moyle and Vondracek 1985). However from the various researches conducted so far the diversity of hydrological pattern appears to be central to the maintenance of habitat heterogeneity and species diversity (Ward et al. 2001, Arrington and Winemiller 2003, Postel and Richter 2003, Welcomme and Halls 2003, Xenopoulos et al. 2005).

It is evident that an understanding of the interaction of the various complex sets of biophysical factors operating in a river over a range of spatial and temporal scale is an urgent necessity for conservationists. A species gets endangered in a given watershed as a result of multiple threats intertwined in a manner difficult to isolate individually (Malmqvist and Rundle 2002). Of importance, in the presently reported study, was the fact that the potential of freshwater fish extinction tends to concentrate in endemic-species-rich tropical and subtropical areas (Oberdorff et al. 1999). Thus, there has been an urgent need to further develop macroecological models predicting regional variation in freshwater fish diversity in areas of highest biological importance to draw up conservation plans to protect species from current and impending threats (such as water use and global environmental change) (Oberdorff et al. 1995).

The studies hitherto conducted in India have not given much attention towards assessing the various fish habitat parameters influencing fish species richness in the rivers except the few investigations (Arunachalam 2000, Johal et al. 2002, Bhat 2003, Das 2007, Sarkar and Bain 2007, Sarkar et al. 2009, Vass et al. 2009, Lakra et al. 2010, Singh et al. 2010). We believe that-even though India possesses a diverse tropical riverine resource and a rich diversity of riverine fish species - the knowledge on the influence of the ecological parameters on the fish species richness patterns has been inadequate and it lacks quantification. In the present communication we attempted to explore the relation between species richness and seven macro ecological parameters related to climate, hydrology, and morphometry of 14 major tropical rivers of India.

\section{MATERIAL AND METHODS}

Fourteen major rivers of India (Brahmaputra, Periyar, Cauvery, Sabarmati, Ganges, Godavari, Tapi, Krishna, Beas, Mahanadi, Sutlej, Mahi, Damodar, Narmada) spanning lat $8^{\circ} 4^{\prime} \mathrm{N}-37^{\circ} 6{ }^{\prime} \mathrm{N}$ and long $68^{\circ} 7^{\prime} \mathrm{E}-97^{\circ} 25^{\prime}$ were studied in the presently reported investigation. These rivers are distributed (Fig. 1) in four climatic zones based on the amount of rainfall; zone I (above $200 \mathrm{~cm}$ rainfall) with more or less moderate temperature, zone II with heavy seasonal rainfall $(100-200 \mathrm{~cm})$ with persistent high temperature, zone III with indiscrete rainfall $(60-100 \mathrm{~cm})$ and fluctuating high temperature in summer and winter, zone IV with very low rainfall (less ten $60 \mathrm{~cm}$ ) with high temperature fluctuation in summer.

The data on fish species richness, climatic and hydrological parameters from the middle stretch of the rivers for the years (1994-2009) were analysed. These data were articulated from different sources of published literature.
The middle stretch was studied following Oberdorff et al. (1995) who suggested an increase in species diversity with decreasing latitude of the rivers.

Fish data. The values for fish species richness were obtained from published sources: David 1963, Dutta et al. 1973, Jhingran and Sehgal 1978, Ross et al. 1985, Jhingran 1991, Menon and Jacob 1996, Zacharias et al. 1996, Dey and Sinha 1998, Anonymous 1999, Ramakrishniah and Selvaraj 2000, Pathak et al. 2001, 2007, Minimol 2004, Nath et al. 2004, Gupta and Gupta 2006, Sinha 2006, Majumder et al. 2007, Negi 2008, Bagra et al. 2009, Beevi and Ramachndran 2009, Chaudhari et al. 2010, Heda 2009, Shinde et al. 2009, Radhakrishnan and Kurup 2010, Froese and Pauly 2011, Jadhav et al. 2011, Rankhamb 2011. The most recent references of fish species numbers were taken into account and were estimated. For example, the data for 250 fish species from the Brahmaputra River were estimated using the Michaelis-Menten method, based on 13 published papers on the river. The maximum species number, however, recorded in a single paper was 221 . We agree with the opinion of Oberdorff et al. (1995), that these values obtained from published literature may be either an underestimate due to inadequate sampling effort or an overestimate due to recent introduction of species in the river, which is not the case for majority of the Indian rivers. Thus, we considered maximum number of species in the river basin during the period of study as fish species richness. It will give a lower bound of the unknown fish species inhabiting the river during the period and thought to be more representative than the estimated species richness for the rivers.

Mean annual water temperature. The mean annual water temperature $\left({ }^{\circ} \mathrm{C}\right)$ for each river was taken as average of available annual temperature in the middle stretch of the river. The sources for the data are Anonymous 1971-2009, 1986-2006.

Mean annual water temperature range. The mean annual water temperature $\left({ }^{\circ} \mathrm{C}\right)$ range data was taken as average of this range available within the period of 1994-2009. As the range is a measure of variability we define this as temperature stability and further analysis and interpretation is based upon this defined variable. The source for the data are Anonymous 1971-2009, 1985-2006, 1986-2006.

Mean annual rainfall in basin area. The annual rainfall $(\mathrm{mm})$ was calculated from the data obtained from Indian Meteorological Department (IMD). We considered the rainfall of the districts/area, through which the middle course of the river passes as rainfall of the middle stretch of the river.

Mean annual discharge. The discharge data $\left(\mathrm{m}^{3} \cdot \mathrm{s}^{-1}\right)$ were acquired from the Central Water Commission. The mean annual discharge values were obtained by taking average of this annual discharge over the period under study (1994-2009) for each river of our interest (Anonymous 1986-2006).

Mean annual sediment load. Data on the annual sediment load $\left(\mathrm{t} \cdot \mathrm{km}^{-2}\right.$ per year) were obtained from the Central Water Commission (e.g., Integrated hydrological 
data book). The mean annual sediment load is the average the centre of each river basin (weighted by the length of of the available annual sediment loads in the middle stretch of the rivers (Anonymous 1986-2006). river reaches at various latitude).

Total surface area of drainage basin. Total area of obtained from: Anonymous (1958, 1976, 1981, 1986, drainage basin $\left(\mathrm{km}^{2}\right)$ was obtained from the Central 1988, 1991, 1993, 1996, 2000, 2006), (1971-2009), Water Commission and the Central Pollution Control (1985-2006), (1986-2006), (1991-2005), (2003), (2004), Board. (Anonymous 1985-2006, 1986-2006).

(2006), Dasgupta (1984), Yadava and Sugunan (1992),

Mean latitude. Mean latitude of river basin was taken Chakrapani and Subramanian (1993), Singh et al. (2003), as average of latitude. The values for mean latitude are for Moza and Mishra (2004), Vass et al. (2008).

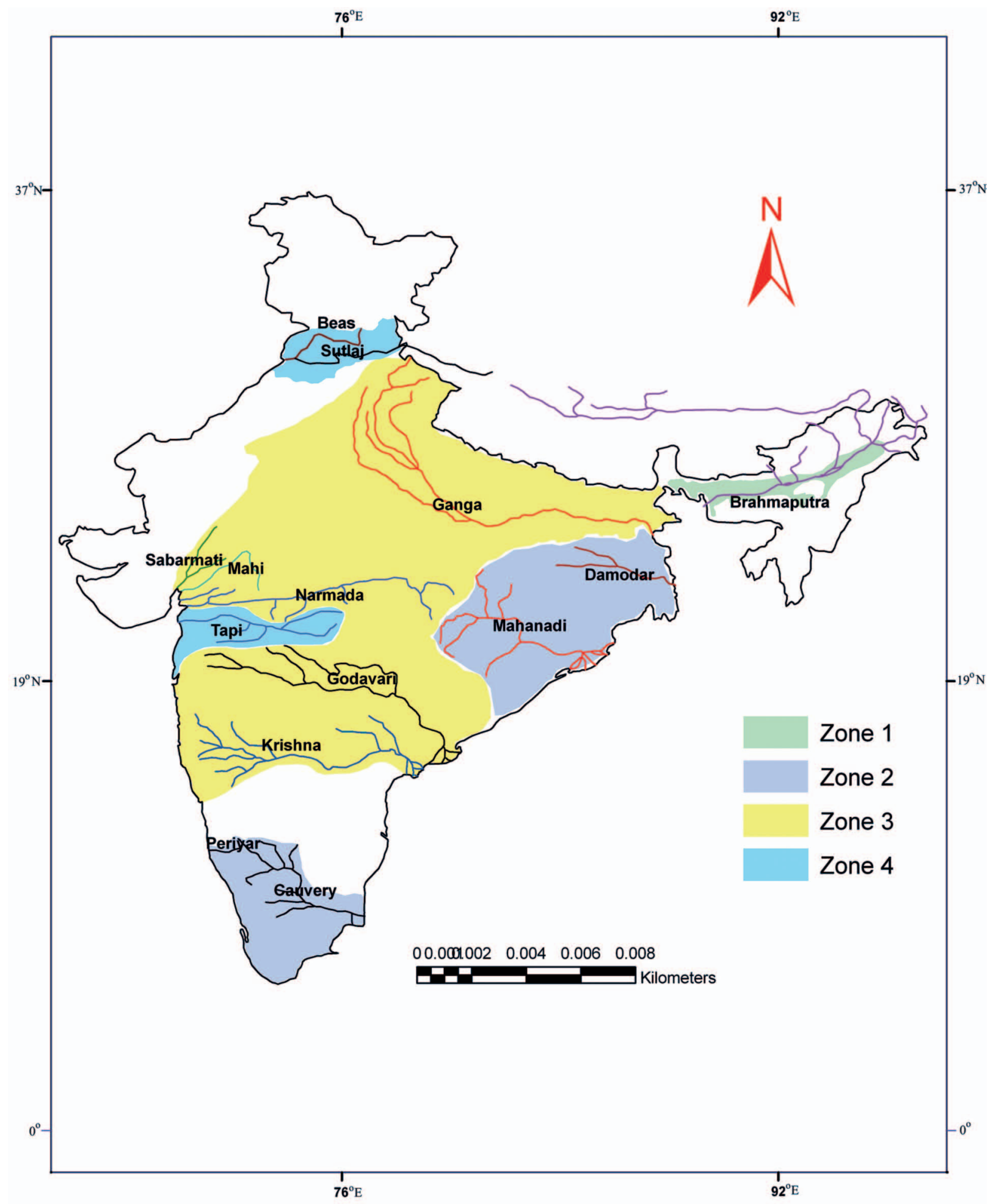

Fig. 1. Map of the study area, depicting rivers and the climatic zones in India 
Statistical analysis. Anticipating the compounding effects of climatic, hydrological, and morphometric factors on fish species richness in rivers, it is of substantive importance to extract main factors from the complex system of climatic and hydrological interaction in the river system under study and thereafter quantitatively determine contributing factors and their relative importance to influence river fish species richness. Accordingly, statistical analyses were performed in two steps.

In the first step, we employed principal factor analysis (PFA) (Jolliffe 2002) to identify main factors that explain climato-hydrological variability in the river system considered in the present study. This also eliminates the multicollinearity present among the variables. Statistical test of significance for Pearson's correlation between each pairs of explanatory variable was conducted to detect multicollinearity. The number of factors was selected by the help of scree plot and of the plot of explained cumulative variance. Standard varimax rotation of factors component was performed for realistic interpretation of the extracted factors.

In the second step, contributory ecological factors of fish species richness were determined under generalised linear model (GLM) framework (McCullagh and Nelder 1989). In contrast to classical multivariate regression under normal error, this is more general approach that analyses nonnormal data in a better way. Fish species richness being quantified by counted number it is more realistic to model this data under Poisson error term than under normal error term as because normality assumption usually violates for species richness data. Though many workers (Oberdorff et al. 1995) employed classical multivariate regression approach under log transformations, this was an approximate method and might lead to inaccurate results. Recently, GLM is commonly used to model fish species richness (Leprieur et al. 2008). Blanchet et al. (2009) extended this idea and exploited the approach in a more efficient way to explain context-dependent determinants of non-native fish species richness in global river system. Our approach differs from aforesaid method in terms of tackling collinearity among explanatory variables and extraction of new interpretable factors of fish species richness. Instead of regressing all the perceived influential variables on fish species richness, we incorporated only the extracted factors obtained in the first step under GLM framework with Poisson error.

All the statistical analyses were performed in SAS version 9.2 and $R$ version 2.12.1 (Anonymous 2006-2008, 2001). Principal Factor analysis was performed in SAS and output from SAS was further analysed in R 2.12.1 under GLM framework.

In case of multiple model comparisons we chose the Akaike information criterion (AIC) (Akaike 1974) which is available in the software. Though statistical significance of GLM model was available in the software, model accuracy in terms of co-efficient of determination $\left(R^{2}\right)$ is not available in any of the above-mentioned software. We computed it by using the basic formula:

$$
R^{2}=1-\frac{\text { Residual Deviance }}{\text { Null Deviace }}
$$

where null and residual deviance are obtained from analysis of deviance module available in R for GLM fitting.

\section{RESULTS AND DISCUSSION}

The pair-wise Pearson's correlation coefficients of explanatory variables under study and the corresponding statistical test of significance are shown in Table 1. There is a clear indication of multicollinearity among the explanatory variables. For example, correlation between surface area of drainage basin and weighted latitude was highly significant $(r=0.96, P<0.001)$. This multicollinearity would produce spurious coefficient of deter-

Table 1

Pearson Correlation coefficients among explanatory variables

\begin{tabular}{|c|c|c|c|c|c|c|c|}
\hline $\begin{array}{l}\text { Explanatory } \\
\text { Variables }\end{array}$ & 1 & 2 & 3 & 4 & 5 & 6 & 7 \\
\hline 1 & 1.000 & & & & & & \\
\hline 2 & $\begin{array}{c}0.209 \\
(0.474)\end{array}$ & 1.000 & & & & & \\
\hline 3 & $\begin{array}{c}0.572^{\mathrm{s}} \\
(0.033)^{\mathrm{s}}\end{array}$ & $\begin{array}{c}0.596^{\mathrm{s}} \\
(0.025)^{\mathrm{s}}\end{array}$ & 1.000 & & & & \\
\hline 4 & $\begin{array}{c}0.180 \\
(0.539)\end{array}$ & $\begin{array}{c}0.784^{\mathrm{s}} \\
(<0.001)^{\mathrm{s}}\end{array}$ & $\begin{array}{c}0.678^{\mathrm{s}} \\
(0.008)^{\mathrm{s}}\end{array}$ & 1.000 & & & \\
\hline 5 & $\begin{array}{c}0.549^{\mathrm{s}} \\
(0.041)^{\mathrm{s}}\end{array}$ & $\begin{array}{c}0.033 \\
(0.910)\end{array}$ & $\begin{array}{c}0.689^{\mathrm{s}} \\
(0.006)^{\mathrm{s}}\end{array}$ & $\begin{array}{c}0.052 \\
(0.859)\end{array}$ & 1.000 & & \\
\hline 6 & $\begin{array}{c}0.596^{\mathrm{s}} \\
(0.024)^{\mathrm{s}}\end{array}$ & $\begin{array}{c}-0.022 \\
(0.941)\end{array}$ & $\begin{array}{c}0.649^{\mathrm{s}} \\
(0.012)^{\mathrm{s}}\end{array}$ & $\begin{array}{l}-0.020 \\
(0.946)\end{array}$ & $\begin{array}{c}0.960^{\mathrm{s}} \\
(<0.0001)^{\mathrm{s}}\end{array}$ & 1.000 & \\
\hline 7 & $\begin{array}{c}0.113 \\
(0.700)\end{array}$ & $\begin{array}{l}-0.049 \\
(0.868)\end{array}$ & $\begin{array}{c}-0.152 \\
(0.603)\end{array}$ & $\begin{array}{c}-0.190 \\
(0.516)\end{array}$ & $\begin{array}{c}0.145 \\
(0.620)\end{array}$ & $\begin{array}{c}0.091 \\
(0.757)\end{array}$ & 1.000 \\
\hline
\end{tabular}

Explanatory variables: $1=$ temperature stability, $2=$ rainfall, $3=$ discharge, $4=$ sediment load, $5=$ surface area of drainage basin, $6=$ weighted latitude, $7=$ water temperature; Values within parenthesis indicate $P$-values $\left(\operatorname{Prob}>|\mathrm{r}|\right.$ under $\left.\mathrm{H}_{0}: \rho=0\right)$; Statistical significance level of below 0.05 was marked with a superscript letter $\left({ }^{\mathrm{S}}\right)$. 
mination in the GLM and thus might mislead the results.

We eliminate this source of error due to multicollinearity by using principal factor analysis (PFA). The analysis showed that three factors (eigenvalue $\geq 1$, a thumb rule for number of factors selection) could be selected to explain reasonable amount of variability $(88.7 \%$ ) for further analysis (Fig. 2). However, the variables were not well segregated in defining the extracted factor in a meaningful way. Though 4th factor (eigenvalue $=0.51$ ) explain very little amount of variation $(7.3 \%)$, factors interpretation became meaningful with the inclusion of this factor. In addition such inclusion ascertained $96 \%$ of total variability present in the included climate-hydro and morphometric variables in the study, which restricts us to retain only 4 factors.

Factor interpretation. A river is a fluvial hydrosystem comprising the river channel, riparian zone, floodplain, and alluvial aquifer and the system is influenced not only by hydrological and geomorphological changes longitudinally but also laterally and vertically and by temporal changes (Ward 1989, Arthington and Welcomme 1995). These processes consequently determine the habitat heterogeneity for fish. The ecological response expressing ecological integrity in terms of species richness in the river will be in relation to the above multiple drivers and not a single one. As

\section{Scree plot}

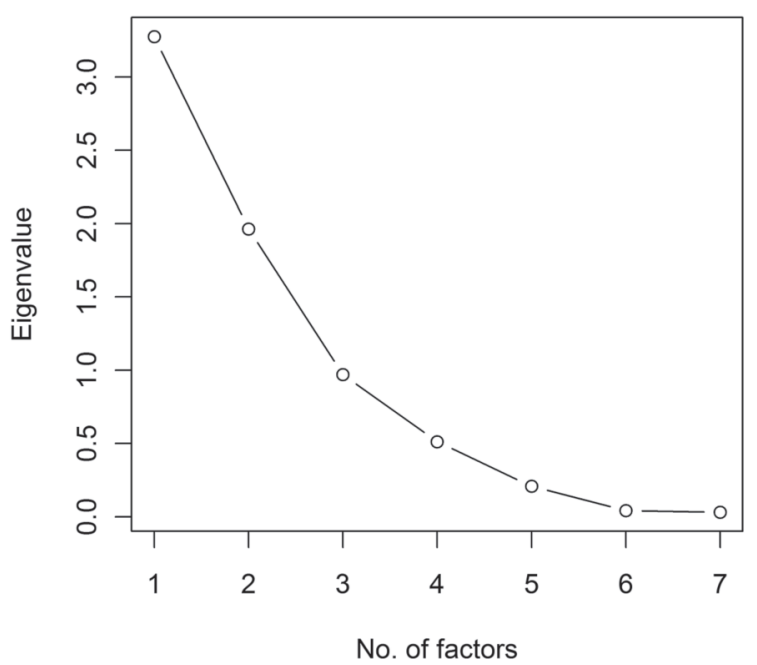

observed by (Kennard et al. 2007, Stewart-Koster et al. 2007, Kennen et al. 2008, Konrad et al. 2008) the ecological integrity in rivers is reflected not only by the river flow but also by the water quality and habitat structure. Therefore to extract determinant factors of fish species richness from the complex climate-hydro and morphometric variables interaction operating in the river systems of India, we took the help of factor loading patterns of each variable under study.

The loading patterns of each variable for varimax rotated state are depicted in Table 2 . We determined that factor 4 is dominated by the influence of temperature stability (loading $=0.906$ ) where as factor 3 is explaining the variability of the water temperature (loading $=0.992$ ). This is clearly depicted in Fig. 3 in which the gradients of temperature stability towards factor 4 and of water temperature towards factor 3 are almost zero. Moreover, extent of contribution (length of the line in Fig. 3) is very near to unit circle. This leads us to define factor 4 as temperature stability and factor 3 as water temperature. Changes in water temperature occur less abruptly, allowing fish (as opposed to terrestrial organisms) to move into more favourable conditions, thus avoiding the potentially lethal effects of temperature variation.

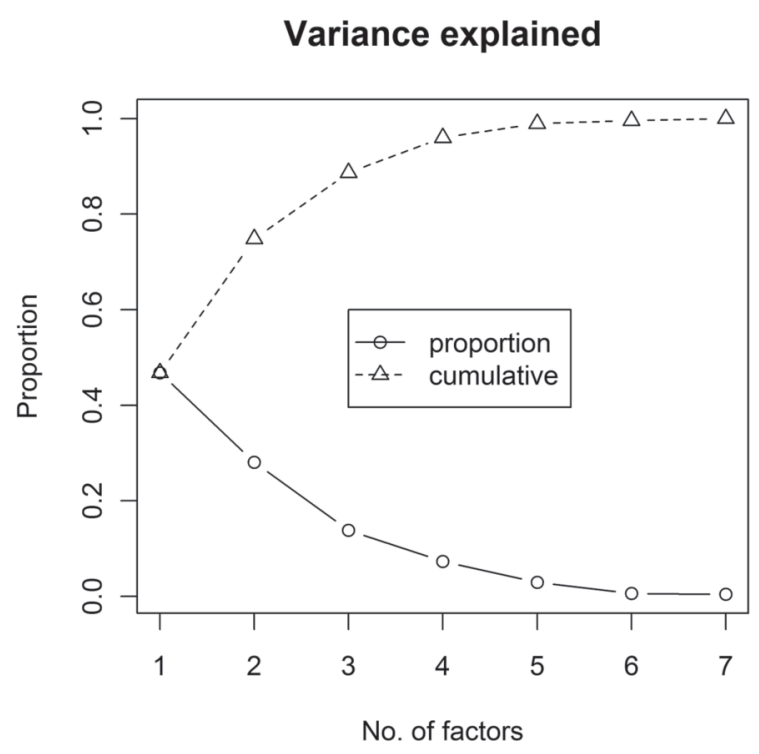

Fig. 2. Scree plot and variance explained for factor selection under PFA

Table 2

Varimax rotated factor loading of each variable

\begin{tabular}{lcccc}
\hline \multirow{2}{*}{ Variable } & \multicolumn{3}{c}{ Varimax rotated factor patterns } \\
\cline { 2 - 4 } & Factor 1 & Factor 2 & Factor 3 & Factor 4 \\
\hline Temperature stability & 0.391 & 0.149 & 0.062 & 0.906 \\
Rainfall & -0.029 & 0.936 & 0.047 & 0.094 \\
Discharge & 0.370 & 0.864 & -0.155 & 0.247 \\
Sediment load & 0.028 & 0.943 & -0.135 & 0.032 \\
Surface area of drainage basin & 0.971 & 0.036 & 0.092 & 0.173 \\
Weighted latitude & 0.954 & -0.043 & 0.0287 & 0.254 \\
Water temperature & 0.054 & -0.080 & 0.992 & 0.047 \\
\hline
\end{tabular}


In the similar way we identify (Fig. 3) that surface area of drainage basin and weighted latitude are main contributory variables for factor 1 . The surface area of the river basin has a dominating effect on the species richness, where bigger the surface area of the river basin the greater would be the diversity of the fish habitats and greater the number of fish species that would be available (Oberdorff et al. 1995, Guégan et al. 1998). The other variable, latitude has also an established influence on species richness. Fish assemblages in the down stream regions of the river exhibit complex fish assemblage as a function of increased complexity and extent of environment (Welcomme 2002) and in general the species diversity increases with decreasing latitude (Guégan et al. 1998). This factor 1 can be termed 'surface area of the river basin'. The factor 2 based on the gradient (Fig. 3) and loading (Table 2) is observed to be the integrated effect of rainfall, discharge and sediment load.

Rainfall is one of the renewal sources of water and greatly influence the water retentiveness of the river. The intra- and inter-annual flood level in the river during the monsoon season have a significant effect on the geomorphological and sedimentary process and greatly amplify the hydrological connectivity in the river (Arthington et al. 2003). Where as a sequential decline in rainfall disrupt the connectivity (Lake 2003). Changes in sedimentary processes can affect not only the quantity of fish habitat available but also its quality, especially the type of substrate available (Arthington et al. 2003).

Discharge in the river channel is an index of ecological space and habitat heterogeneity for fish survival, growth and reproduction. Discharge and sediment load also plays important role in determining the water depth and habitat space available for riverine fish, though there are other parameters e.g., water extraction to influence water depth.

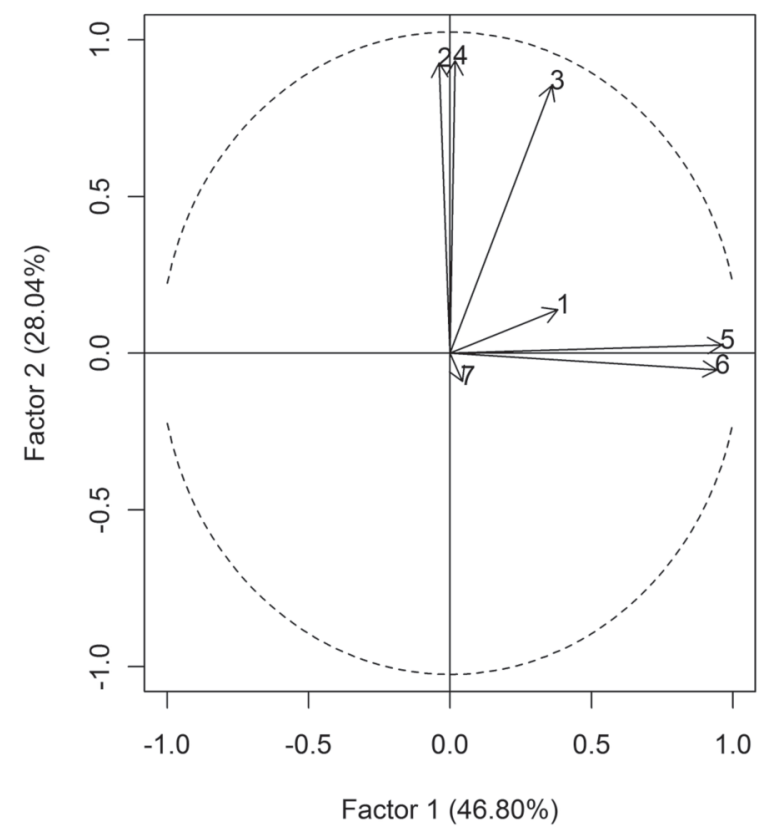

Therefore the discharge or flow regime determine the ecological consequence in a river resulting in the sustenance or loss of fish species (Arthington et al. 2003), these three variables related to river hydrology and morphology thus significantly influence the riverine habitat structure for fish and their alteration may lead to changes in fish species richness in the river. We call this compounded effect of the three variables representing factor 2 as 'Fish habitat availability potential of river'.

After redefining the variables in terms of four factors as 'regional surface area of river basin', 'fish habitat availability potential of the river', water temperature and temperature stability, we computed the factors' standardized scores for each river for utilisation in GLM framework. This transformation helped us to determine quantitatively the relative contribution of these factors on the fish species richness in the river. In our GLM framework, we consider these four factors as independent variables and fish species richness as dependent variables and fitted the model assuming Poisson error term with log-linear link function.

Model diagnostics and refinement. Goodness of fit for model was tested based on the Pearson's Chi-square $\left(\chi^{2}\right)$ statistic obtained from maximum likelihood fitting of the model. It turns out to be statistically significant $\left(\chi^{2}=37.36\right.$, $\mathrm{df}=9, P<0.001)$ for the model. Model accuracy for prediction was evaluated on the basis of the co-efficient of determination $R^{2}(=0.60)$. Though the model was statistically significant, it could explain only $60 \%$ of variation in fish species richness that reflects a bit poor predictive power of the model. It motivates us for further model diagnostics based on graphical method. We plotted the predicted values obtained from the model against observed values of fish species richness and depicted in Fig. 4 to identify outlier or influential data points. It is

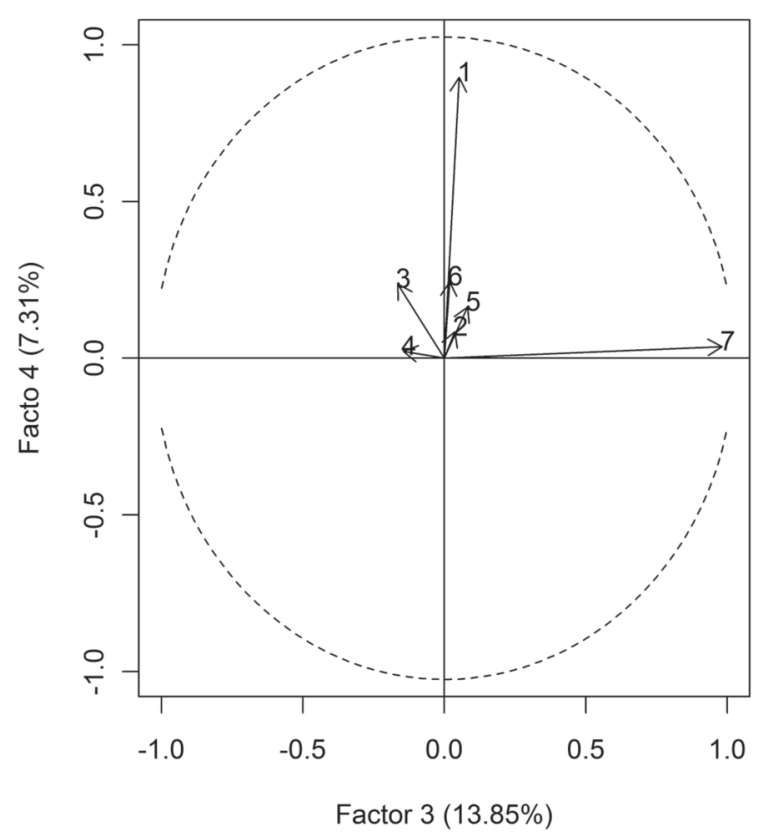

Fig. 3. Factors pattern after varimax rotation. Following are the symbol descriptions: 1: temperature stability, 2: rainfall, 3: discharge, 4: sediment load, 5: surface area of drainage basin, 6: weighted latitude, 7: water temperature 
observed that (Fig. 4 a) one point corresponding to the Mahanadi River lies far below from ideal predictive line. The other points are reasonably closer to the same. So, the Mahanadi was detected as outlier and become nuisance for prediction overall species richness by the model for Indian river system.

To enhance the model's predictive power we deleted the nuisance observation corresponding to the Mahanadi River from the model and re-fitted the model for the remaining 13 rivers. For clear distinction, the former model was named as Model 1 that includes data for all the rivers and the later one was named as Model 2 that excluded the influential data corresponding to the Mahanadi. The results obtained from Model 1 and Model 2 were shown in (Table 2) for a comparative study and the diagnostic plot was shown in (Fig. 4b). The diagnostic plot for Model 2 (Fig. 4b) now ensured good agreement between observed and predicted fish species richness. The $R^{2}$ value $(=0.91)$ significantly improved (Table 3 ) after deleting the abnormal data corresponding to the Mahanadi River.

Between the two models considered, Model 2 produced higher $R^{2}$ value and lower AIC value as compared to that of Model 1. This indicates that performance of Model 2 is better than that of Model 1. So we selected Model 2 for further interpretation of the results. It was observed (Table 3 ) that all the four extracted factors were statistically significant at least $5 \%$ level of significance $(P<0.05)$. However, relative contribution of the hydro and morphometric factors (e.g., regional surface area of river basin and Fish habitat availability potential of river) is greater on fish species richness as compared to that of water temperature and temperature stability. It is evident from the result (Table 3 ) that the factor regional surface area of river basin is most influential determinants (0.439) of river fish species richness followed by fish habitat availability potential of river (0.326). Both of them have a positive impact on the fish species richness and alteration in those two factors would significantly change species richness in the rivers under study.

Water temperature and temperature stability have very little effect on the fish species richness, though they are statistically significant. Water temperature has positive effect on fish species richness, whereas temperature stability has the negative effect on fish species richness in Indian river system.

The predicted species richness for each river is depicted in Fig. 5. The 95\% confidence interval along with observed values was also plotted for comparison. It was observed that the values of Mahi, Narmada, Periyar, and Sabarmati were not inside the $95 \%$ confidence interval
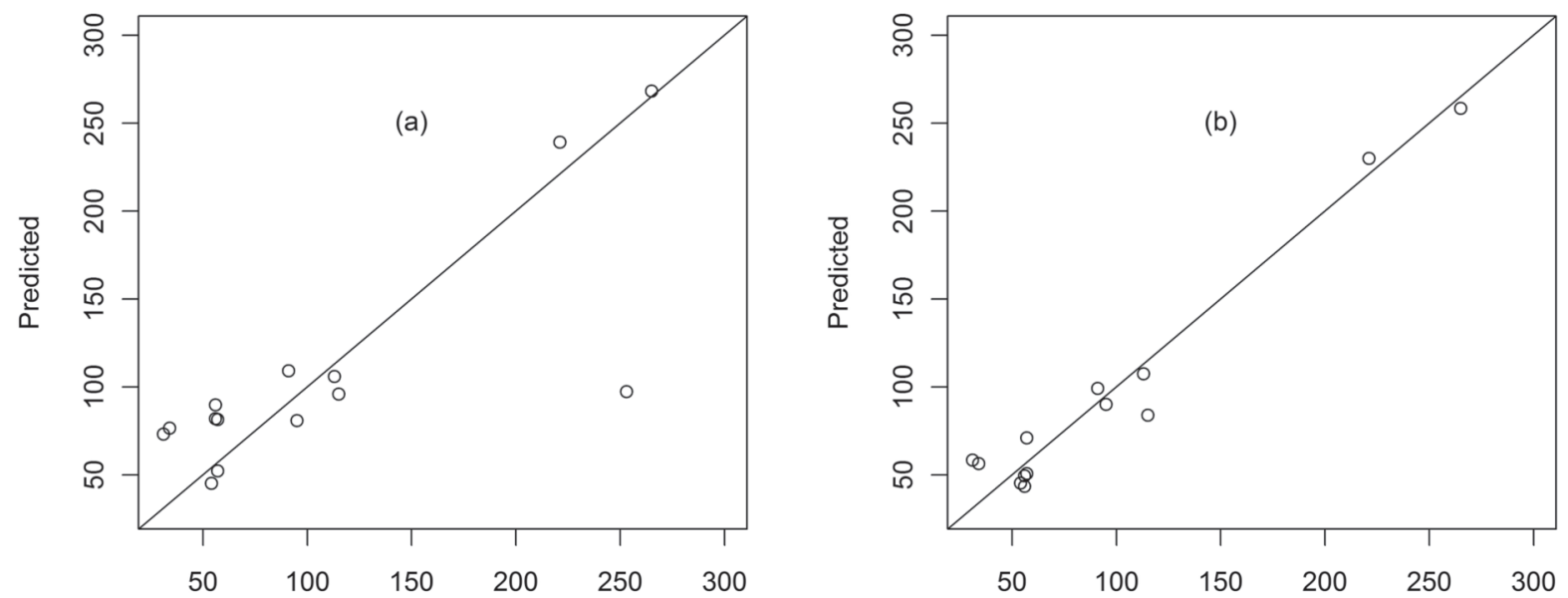

Fig. 3. Factors pattern after varimax rotation. Following are the symbol descriptions: 1: temperature stability, 2: rainfall, 3: discharge, 4: sediment load, 5: surface area of drainage basin, 6: weighted latitude, 7: water temperature

Model fitting under GLM framework; Model 1 is based on all the 14 rivers; Model 2 is based on data with exclusion of influential/outlier river (Mahanadi) identified by model diagnostics

\begin{tabular}{lcccccc}
\hline \multirow{2}{*}{ Factor } & \multicolumn{3}{c}{ Model 1 } & \multicolumn{3}{c}{ Model 2 } \\
\cline { 2 - 7 } & Estimate & SE & $P$ & Estimate & SE & $P$ \\
\hline Intercept & 4.548 & 0.029 & $<0.001$ & 4.368 & 0.034 & $<0.001$ \\
Regional surface area & 0.331 & 0.021 & $<0.001$ & 0.439 & 0.024 & $<0.001$ \\
Fish habitat availability potential & 0.296 & 0.021 & $<0.001$ & 0.326 & 0.021 & $<0.001$ \\
Water temperature & 0.165 & 0.037 & $<0.001$ & 0.078 & 0.038 & 0.042 \\
Temperature stability & 0.104 & 0.028 & 0.0003 & -0.081 & 0.035 & 0.021 \\
Model accuracy & $R^{2}=0.60, \mathrm{AIC}=376.5, \mathrm{df}=9$ & $R^{2}=0.910, \mathrm{AIC}=137.9, \mathrm{df}=8$ \\
\hline
\end{tabular}

$\mathrm{SE}=$ standard error, $R^{2}=$ coefficient of determination, $\mathrm{AIC}=$ Akaike information criterion (Akaike 1974), $\mathrm{df}=\mathrm{degrees}$ of freedom of residual deviance. 
indicating a somewhat low performance in predicting. breeding and recruitment. This provided great variety of However, they are not too far from the predictive values. For all other rivers predictions were quite strong. ecological habitats, for harbouring rich ichthyofaunal diversity. However, in recent years the fragmentation of

The river Mahanadi remained an outlier in spite of being rich in fish species. It can possibly be explained by the river basin by series of dams (15 in numbers) have the fact that prior to the coming up of the large number of disconnected the main channel from their flood plain wethydraulic structures the overall physical and biological lands. Thus, the fish habitat availability potential has been structure and function of the Mahanadi River system, was reduced. This type of fragmentation of the continuity of conducive to the maintaining of the ecological integrity of the river remains unaccounted in the model. As a result the river. The transport of water sediment and nutrients the model reflects the predicted species richness to be downstream was adequate. The floodplains were connect- much below the observed number. The percentage change ed providing vital lateral connectivity to the cyprinids for in fish species richness recorded with respect to percent-

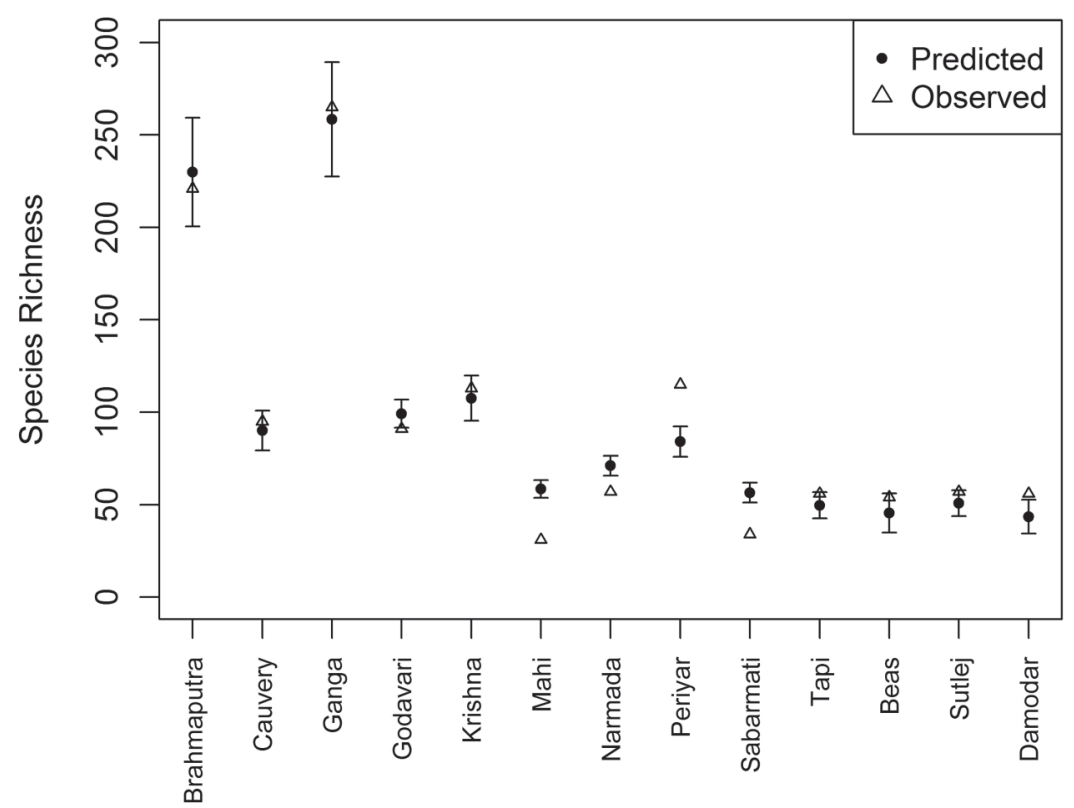

Fig. 5. The 95\% confidence interval with predicted and observed values of fish species richness of each of the studied Indian rivers

Table 4

Predictive changes (percentage point) of fish species richness in different rivers due to change (percentage point) in individual factor scores

\begin{tabular}{|c|c|c|c|c|c|c|c|c|}
\hline \multirow{2}{*}{ River } & \multicolumn{2}{|c|}{ Regional surface Area } & \multicolumn{2}{|c|}{$\begin{array}{c}\text { Fish habitat availability } \\
\text { potential }\end{array}$} & \multicolumn{2}{|c|}{ Water Temperature } & \multicolumn{2}{|c|}{ Temperature Stability } \\
\hline & $-5 \%$ & $-10 \%$ & $-5 \%$ & $-10 \%$ & $5 \%$ & $10 \%$ & $5 \%$ & $10 \%$ \\
\hline Brahmaputra & -0.2 & -0.4 & -5.5 & -11.4 & 0.2 & 0.4 & 0 & -0.1 \\
\hline Cauvery & -0.3 & -0.5 & -0.4 & -0.8 & 0.1 & 0.2 & -0.7 & -1.3 \\
\hline Ganga & -7.0 & -14.5 & -0.4 & -0.7 & 0 & 0.1 & -0.4 & -0.8 \\
\hline Godavari & -1.2 & -2.5 & -0.5 & -1.0 & 0.2 & 0.5 & -0.2 & -0.4 \\
\hline Krishna & -1.1 & -2.3 & -0.5 & -1.0 & 0.4 & 0.8 & -0.5 & -1 \\
\hline Mahi & -1.0 & -1.9 & -0.6 & -1.3 & 0 & 0.1 & 0 & -0.1 \\
\hline Narmada & -0.3 & -0.6 & -0.8 & -1.6 & 0.1 & 0.2 & 0 & -0.1 \\
\hline Periyer & -1.4 & -2.9 & -1.1 & -2.1 & 0.3 & 0.6 & -0.4 & -0.7 \\
\hline Sabarmati & -1.4 & -2.8 & -0.5 & -0.9 & 0.2 & 0.4 & 0 & 0 \\
\hline Tapi & -1.3 & -2.5 & -0.8 & -1.6 & 0.2 & 0.4 & -0.4 & -0.9 \\
\hline Beas & -0.8 & -1.7 & -0.8 & -1.7 & 1.1 & 2.2 & 0 & 0 \\
\hline Sutlej & -1.0 & -2.0 & -1.0 & -2.0 & 0.5 & 1 & -0.2 & -0.5 \\
\hline Damodar & -2.3 & -4.6 & -0.2 & -0.4 & 0.3 & 0.5 & -0.8 & -1.6 \\
\hline
\end{tabular}

$\%=$ percentage point change; (-) indicate loss in fish species. 
age change in each identified factor score is depicted in (Table 4). Applying the results obtained we tried to develop scenarios of losses of riverine fish species richness with respect to 5- and 10 percentage-point reduction in the scores of the identified influential factors viz., Surface area of drainage basin and fish habitat availability potential for each river (Table 4). The score values of each factor were used for comparison in the same scale. The other remaining factors were assumed to be constant while assessing such changes. For example, there will be 14.5 percentage-point loss of species richness in the Ganga River due to 10 percentage-point loss in regional surface area of river basin provided there is no change in the fish habitat availability potential of river, water temperature and water temperature stability. In general, visible changes in fish species richness were found only after 10 percentage-point change of factor score. Relative comparison among rivers shows that the Brahmaputra River is more sensitive to loss of fish species richness (11.4 percentage points) due to loss of fish habitat availability potential of river (10 percentage points) compared to other rivers (Table 3). Similarly the Ganges River will have highest loss of fish species richness due to loss of regional surface area of river basin in comparison to other rivers. While the Beas River may observe increase in species richness (2.2 percentage points) due to 10 percentage-point increase in the temperature score and fish species richness of the Damodar River may decrease by 1.6 percentage points due to 10 percentage-point increase in score of water temperature stability. Though the model produces reasonably good estimates for species loss, increase in species richness is not well explainable from the model prediction. For example, model predicts an increase of 7 percentage points in species richness with an increase of temperature by $1^{\circ} \mathrm{C}$ provided other factors remain unchanged. In natural system hydrological parameters are more prone to change than to change of temperature. As the relative contribution of temperature to change in species richness is very low with respect to hydrological factors (Table 3), change due to temperature will be nullified by the change due to those factors. Other possibility is that hydrological parameters remain unchanged while temperature increases. In this situation, the possibility to increase species richness may occur due to invasion of exotic species and possible shift of warm water species towards colder stretch. This possibility is recently emerging in the Ganges River (Vass et al. 2009, Singh et al. 2010). These factors of invasive species and spatial variability have remained unaccounted in the model and are the limitations of model applicability. This will be of interest for further investigation.

However, the loss in fish species as predicted in the model could be more if the other anthropogenic factors viz., rapid urbanization, industrialization, and intensification of agriculture which are at present affecting the rivers in India is taken into account. These anthropogenic activities have placed a greater demand on water availability in the rivers thereby modifying quantitatively and qualitatively the hydrological cycle in most agro-climatic regions and river basins in India (Mall et al. 2006, Das et al. 2007). At the same time the water quality of the rivers have degraded impacting fish. These affects are likely to be compounded by the impact of climate change in India. Globally the effect of climate change assessed in 273 river basins by Xenopoulos et al. (2005), within which greater than 10 percentage-point reduction in discharge has been predicted by the Anonymous (2001) climate scenario A1 and A2 indicate that the combination of increased evapotranspiration and reduced precipitation as the most important driver of freshwater fish losses. The projection obtained for the Indian rivers also indicated a similar trend (Vass et al. 2009). Future work should consider studying along with hydrological factors, parameters of water quality and exotic species invasion influencing species diversity in the rivers systems of India.

\section{ACKNOWLEDGMENTS}

The authors are grateful to the Indian Council of Agricultural Research, New Delhi, India for providing financial assistance under the Network Project on Impact, Adaptation and Vulnerability of Indian Agriculture to Climate Change in India and to the Director, Central Inland Fisheries Research Institute, Kolkata, India.

\section{REFERENCES}

Akaike H. 1974. A new look at the statistical model identification. IEEE Transactions on Automatic Control 19 (6): 716-723. DOI: $10.1109 /$ TAC.1974.1100705

Anonymous 1958, 1976, 1981, 1986, 1988, 1991, 1993, 1996, 2000, 2006. Handbook on fisheries statistics. Ministry of Agriculture, Department of Agriculture and Cooperation Fisheries Division. Government of India, New Delhi. India.

Anonymous 1971-2009. Annual reports. Central Inland Fisheries Research Institute, Barrackpore. Kolkata, India.

Anonymous 1985-2006. Water quality status and statisticsIndicators of organic pollution-Medium and minor rivers. Central Pollution Control Board, New Delhi, India.

Anonymous 1986-2006. Integrated hydrological data book (non-classified river basins). Central Water Commission, New Delhi, India.

http://www.cwc.nic.in/main/downloads/Integrated_Hydrological_Data_2005.pdf.

Anonymous (1991-2005). Climatic data report. Indian Meteorological Department, Pune, India.

Anonymous 1999. Records of Zoology Survey of India, A. Journal of Indian Zoology 97 (2): 1-267.

Anonymous 2003. State environment related issues. Assam Science Technology and Environment Council, Assam, India. Vol. 2. No. 2.

Anonymous 2004. India's initial national communication (NATCOM) to the United Nations Framework Convention on Climate Change. Government of India. http://www.natcomindia.org/brochure4.pdf.

Anonymous 2006. Handbook of fisheries and aquaculture. Indian Council of Agricultural Research, New Delhi. 
Anonymous 2006-2008. SAS Enterprise Guide, Version 4.2 of SAS system for Windows. SAS Institute, Cary, NC, USA.

Anonymous 2011. R: A language and environment for statistical computing. R Foundation for Statistical Computing, Vienna, Austria. ISBN 3-900051-07-0. http://www.R-project.org.

Arthington A.H., Rall J.L., Kennard M.J., Pusey B.J. 2003. Environmental flow requirements of fish in Lesotho rivers using the DRIFT methodology. River Research and Applications 19 (5-6): 641-666.

DOI: $10.1002 /$ rra. 728

Arthington A.H., Welcomme R.L. 1995. The condition of large river systems of the world. Pp. 44-75. In: Voigtlander C.W. (ed.) Proceedings of the world fisheries congress. IBH Publishing, New Delhi and Oxford.

Arrington D.A., Winemiller K.O. 2003. Organization and maintenance of biological diversity in neotropical floodplain rivers. Pp. 25-36. In: Welcomme R.L., Petr T. (eds.) Proceedings of the Second International Symposium on the Management of Large Rivers for Fisheries. Vol. 2. Food and Agriculture Organization of the United Nations and Mekong River Commission. FAO Regional Office for Asia and the Pacific, Bangkok. RAP Publication 2004/17.

Arunachalam M. 2000. Assemblage structure of stream fishes in the Western Ghats (India). Hydrobiologia 430 (1-3): 1-31. DOI: $10.1023 / \mathrm{A}: 1004080829388$

Bagra K., Kadu K., Nebeshwar-Sharma K., Laskar B.A., Sarkar U.K., Das, D.N. 2009. Ichthyological survey and review of the checklist of fish fauna of Arunachal Pradesh, India. Check List 5 (2): 330-350.

Beevi K.S.J., Ramachandran A. 2009. Checklist of freshwater fishes collected from Ernakulam District, Kerala, India. Journal of Threatened Taxa 1 (9): 493-494.

Bhat A. 2003. Diversity and composition of freshwater fishes in river system of Central Western Ghats, India. Environmental Biology of Fishes 68 (1): 25-38. DOI: 10.1023/A:1026017119070

Blanchet S., Leprieur F., Beauchard O., Staes J., Oberdorff T., Brosse S. 2009. Broad-scale determinants of non-native fish species richness are context-dependent. Proceedings of the Royal Society B 276 (1666): 2385-2394. DOI: $10.1098 / \mathrm{rspb} .2009 .0156$

Bunn S.E., Arthington A.H. 2002. Basic principles and ecological consequences of altered flow regimes for aquatic biodiversity. Environmental Management 30 (4): 492-507. DOI: $10.1007 / \mathrm{s} 00267-002-2737-0$

Chakrapani G.J., Subramanian V. 1993. Rates of the erosion and sedimentation in the Mahanadi River basin, India. Journal of Hydrology 149 (1-4): 39-48.

DOI: 10.1016/0022-1694(93)90098-T

Chaudhari Meena S., Patil Y.B. 2010. Diversity of fish fauna in river Tapi, Bhusawal tahsil. Research Analysis and Evaluation 1 (15): 73-74.

Das M.K. 2007. Environment and fish health: A holistic assessment of inland fisheries in India. Pp. 137-151. In: Goswami U.C. (ed.) Natural and anthropogenic hazards on fish and fisheries. Narendra Publishing House, Delhi, India.

Das M.K., Samanta S., Saha P.K. 2007. Riverine health and impact on fisheries in India. Central Inland Fisheries
Research Institute, Barrackpore, Kolkata Policy Paper No. 1.

Dasgupta S.P. 1984. The Ganga Basin. Part 2. Central Pollution Control Board, New Delhi.

David A. 1963. Fish and fisheries of the Godavari and Krishna river system. Part 1 and 2. Proceedings of National Academy of Sciences B 33 (2): 263-93.

Devi K.R., Indra T.J. 2012. Check list of the native freshwater fishes of India. Zoological Survey of India. http://zsi.gov.in/check_list.html.

Dey D.K., Sinha M. 1998. The Ganga environment and fishery. Central Inland Fisheries Research Institute, Barrackpore, Kolkata, India.

Dutta P., Laha G.C., Chaudhury A., De R.N., Mitra P.M., Pandit P.K., Saha B.K., Dey D.K., Chaudhury A.R., Mazumder H.S., Sarkar N.D., Namasudra A.K., Mandal N.C., Ghosh S.P., Paul A.R. 1973. Fishery resources of the Hooghly-Matlah estuarine system. Central Inland Fisheries Research Institute, Barrackpore, Bulletin No. 19.

Froese R., Pauly D. (eds.) 2011. FishBase. [version 10/2011] http://www.fishbase.org.

Guégan J.-F., Lek S., Oberdorff T. 1998. Energy availability and habitat heterogeneity predict global riverine fish diversity. Nature 391: 382-384. DOI: $10.1038 / 34899$

Gupta S., Gupta P. 2006. General and applied ichthyology (Fish and fisheries). Chand, New Delhi, India.

Heda N.K. 2009. Fish diversity studies of two rivers of the northeastern Godavari basin, India. Journal of Threatened Taxa 1 (10): 514-518.

Hugueny B. 1989. West African rivers as biogeographic islands: Species richness of fish communities. Oecologia 79 (2): 236-243.

Jadhav B.V., Kharat S.S., Raut R.N., Paingankar M., Dahanukar N. 2011. Freshwater fish fauna of Koyna River, northern Western Ghats, India. Journal of Threatened Taxa 3 (1): 1449-1455.

Jhingran V.G. 1991. Fish and fisheries of India. Hindustan Publishing, Delhi, India.

Jhingran V.G., Sehgal K.L. 1978. Coldwater fisheries of India. Inland Fisheries Society of India, Barrackpore, India.

Johal M.S., Tandon K.K., Tyor A.K., Rawal Y.K. 2002. Fish diversity in different habitats in the streams of lower middle Western Himalayas. Polish Journal of Ecology 50 (1): 45-56.

Jolliffe I.T. 2002. Principal Component Analysis. 2nd edn. Springer-Verlag, New York.

Kennard M.J., Olden J.D., Arthington A.H., Pusey B.J., Poff N.L. 2007. Multiscale effects of flow regime and habitat and their interaction on fish assemblage structure in eastern Australia. Canadian Journal of Fisheries and Aquatic Sciences 64 (10): 1346-1359.

DOI: $10.1139 /$ F07-108

Kennen J.G., Kauffman L.J., Ayers M.A., Wolock D.M., Colarullo S.J. 2008. Use of an integrated flow model to estimate ecologically relevant hydrologic characteristics at stream biomonitoring sites. Ecological Modelling 211 (1-2): 57-76. DOI: 10.1016/j.ecolmodel.2007.08.014

Konrad C.P., Brasher A.M.D., May J.T. 2008. Assessing streamflow characteristics as limiting factors on benthic 
invertebrate assemblages in streams across the western United States. Freshwater Biology 53 (10): 1983-1998. DOI: $10.1111 / \mathrm{j} .1365-2427.2008 .02024 . \mathrm{x}$

Lake P.S. 2003. Ecological effects of perturbation by drought in flowing waters. Freshwater Biology 48 (7): 1161-1172. DOI: 10.1046/j.1365-2427.2003.01086.x

Lakra W.S., Sarkar U.K., Kumar R.S., Pandey A., Dubey V.K., Gusain, O.P. 2010. Fish diversity, habitat ecology and their conservation and management issues of a tropical river in Ganga basin, India. Environmentalist 30 (4): 306-319. DOI: $10.1007 / \mathrm{s} 10669-010-9277-6$

Leprieur F., Beauchard O., Blanchet S., Oberdorff T., Brosse S. 2008. Fish invasions in the world's river systems: When natural processes are blurred by human activities. PLoS Biology 6 (2): e28.

DOI: 10.1371/journal.pbio.0060028

Majumder M., Roy P.K., Mazumdar A. 2007. Optimization of the water use in the river Damodar in West Bengal in India: an integrated multi-reservoir system with the help of artificial neural network. Journal of Engineering, Computing and Architecture 1 (2): [Without agination: 12 pages.]

Mall R.K., Gupta A., Singh R., Singh R.S., Rathore L.S. 2006. Water resources and climate change: An Indian perspective. Current Science 90 (12): 1610-1626.

Malmqvist B., Rundle S. 2002. Threats to the running water ecosystems of the world. Environmental Conservation 29 (2): 134-153. DOI: $10.1017 / \mathrm{S} 0376892902000097$

McCullagh P., Nelder J.A. 1989. Generalized linear models. 2nd edn. Chapman and Hall, London.

Menon A.G.K., Jacob P.C. 1996. Crossocheilus periyarensis, a new cyprinid fish from Thannikudy (Thekkady), Kerala, India. Journal of the Bombay Natural History Society 93: 62-64.

Minimol K.C. 2004. Fish diversity in Periyar Tiger reserve. In: Veeramani A. (ed.) Abstracts of the studies conducted on Periyar Tiger reserve.

http://www.periyarfoundation.org/pdf/abstractsofstudies.pdf.

Moyle P.B., Vondracek B. 1985. Persistence and structure of the fish assemblage in a small California stream. Ecology 66 (1): 1-13. DOI: $10.2307 / 1941301$

Moza U., Mishra D.N. 2004. River Beas ecology and fishery. Central Inland Fisheries Research Institute, Barrackpore, Bulletin No. 150.

Nath D., Mishra R.N., Karmakar H.C. 2004. The Hooghly estuarine system-The ecological flux, fishery resources and Production. Central Inland Fisheries Research Institute, Barrackpore, Bulletin No. 130.

Negi R.K. 2008. Impact of hydrological projects on the fishery of Pongdam Reservoir Wetland and Gobindsagar Reservoir in Himachal Pradesh (India). Pp. 2001-2008. In: Sengupta M., Dalwani R. (eds.) Proceedings of Taal 2007: The 12th World Lake Conference.

Oberdorff T., Guégan J.-F., Hugueny B. 1995. Global scale patterns of fish species richness in rivers. Ecography 18 (4): 345-352. URL: http://www.jstor.org/stable/3682818.

Oberdorff T., Hugueny B., Guégan J.-F. 1997. Is There an Influence of Historical Events on Contemporary Fish
Species Richness in Rivers? Comparisons between Western Europe and North America. Journal of Biogeography 24 (4): 461-467.

Oberdorff T., Lek S., Guégan J.-F. 1999. Patterns of endemism in riverine fish of the Northern Hemisphere. Ecology Letters 2 (2): 75-81. DOI: 10.1046/j.1461-0248.1999.t01-2-22051.x

Pathak V., Mahavar L.R., Sarkar A. 2001. Ecological status and production dynamics of a stretch of river Mahanadi. Journal of Inland Fisheries Society India 33 (1): 25-31.

Pathak V., Srivastava N.P., Chakraborty P.K., Das A.K. 2007. Ecological status and production dynamics of river Mahanadi. Central Inland Fisheries Research Institute, Barrackpore, Bulletin No. 149.

Poff N.L., Zimmerman J.K.H. 2010. Ecological responses to altered flow regimes: a literature review to inform the science and management of environmental flows. Freshwater Biology 55 (1): 194-205.

DOI: $10.1111 / j .1365-2427.2009 .02272 . x$

Postel S., Richter B. 2003. Rivers for life: Managing water for people and nature. Island Press, Washington, DC.

Pusey B.J., Kennard M.J. 1996. Species richness and geographical variation in assemblage structure of the freshwater fish fauna of the wet tropics region of northern Queensland. Marine and Freshwater Research 47 (3): 563-573. DOI: 10.1071/MF9960563

Radhakrishnan K.V., Kurup B.M. 2010. Ichthyodiversity of Periyar Tiger Reserve, Kerala, India. Journal of Threatened Taxa 2 (10): 1192-1198.

Ramakrishniah M., Selvaraj C. 2000. River Godavari-environment and fishery. Central Inland Fisheries Research Institute, Barrackpore, Bulletin No.102.

Rankhamb S.V. 2011. Ichthyofaunal diversity of Godavari River at Mudgal Tq. Pathri, Dist. Parbhani. Recent Research in Science and Technology 3 (12): 11-13.

Ross S.T., Matthews W.J., Echelle A.A. 1985. Persistence of stream fish assemblages: effects of environmental change. American Naturalist 126 (1): 24-40.

Sarkar U.K., Bain M.B. 2007. Priority habitats for the conservation of large river fish in the Ganges river basin. Aquatic Conservation: Marine and Freshwater Ecosystems 17 (4): 349-359. DOI: $10.1002 /$ aqc. 782

Sarkar U.K., Gupta B.K., Lakra W.S. 2009. Biodiversity, ecohydrology, threat status and conservation priority of the freshwater fishes of river Gomti, a tributary of river Ganga (India). Environmentalist 30 (1): 3-17.

DOI: $10.1007 / \mathrm{s} 10669-009-9237-1$

Shinde S.E., Pathan T.S., Raut K.S., Bhandare R.Y., Sonawane D.I. 2009. Fish biodiversity of Pravara River at Pravara Sangam District Ahmednagar, (M.S.) India. World Journal of Zoology 4 (3): 176-179.

Singh A.K., Pathak AK., Lakhra W.S. 2010. Invasion of an exotic fish-common carp Cyprinus carpio L. (Actonopterigii: Cypriniformes: Cyprinidae ) in the Ganga River, India and its impact. Acta Ichthyologica et Piscatoria 40 (1): 11-19. DOI: $10.3750 / A I P 2010.40 .1 .02$

Singh D.N., Murugesan V.K., Das A.K., Rao D.S.K., Palaniswamy R., Manoharan S. 2003. River Cauvery- 
Environment and Fishery. Central Inland Fisheries Research Institute, Barrackpore, Bulletin No. 119.

Sinha M. 2006. Riverine fisheries of India. Pp. 142-157. In: Sharma R.P. (ed.) Handbook of fisheries and aquaculture. Indian Council of Agricultural Research, New Delhi, India.

Stewart-Koster B., Kennard M.J., Harch B.D., Sheldon F., Arthington A.H., Pusey B.J. 2007. Partitioning the variation in stream fish assemblages within a spatio-temporal hierarchy. Marine and Freshwater Research 58 (7): 675-686. DOI: 10.1071/MF06183

Vass K.K., Samanta S., Suresh V.R., Katiha P.K., Mandal S.K. 2008. Current status of river Ganges. Central Inland Fisheries Research Institute, Barrackpore, Bulletin No. 152.

Vass K.K., Das M.K., Srivastava P.K., Dey S. 2009. Assessing the impact of climate change on inland fisheries in River Ganga and its plains in India. Aquatic Ecosystem Health and Management 12 (2): 138-151. DOI: $10.1080 / 14634980902908746$

Ward J.V. 1989. The four-dimensional nature of lotic ecosystems. Journal of the North American Benthological Society 8 (1): $2-8$.

Ward J.V., Tockner K., Uehlinger U., Malard, F. 2001.Understanding natural patterns and processes in river corridors as the basis for effective river restoration. Regulated Rivers: Research and Management 17 (4-5): 311-323.

DOI: $10.1002 /$ rrr.646
Welcomme R., Halls A. 2003. Dependence of tropical river fisheries on flow. Pp. 267-284. In: Welcomme R.L., Petr T. (eds.). Proceedings of the Second International Symposium on the Management of Large Rivers for Fisheries. Vol. 2. FAO Regional Office for Asia and the Pacific, Bangkok. RAP Publication 2004/17.

Welcomme R.L. 1985. River fisheries. FAO Fisheries Technical Paper 262.

Welcomme R.L. (ed.) 2002. Inland fisheries: ecology and management. Fishing News Books. Blackwell Science, London.

Xenopoulos M.A., Lodge D.M., Alcamo J., Märker M., Schulze K., Van Vaureen D.P. 2005. Scenarios of freshwater fish extinctions from climate change and water withdrawal. Global Change Biology 11 (10): 1557-1564. DOI: $10.1111 /$ j.1365-2486.2005.001008.x

Yadava Y.S., Sugunan V.V. 1992. Factors relating to decline of fisheries in the river Brahmaputra. Central Inland Fisheries Research Institute, Barrackpore, Bulletin No. 60.

Zacharias V.J., Bharadwaj A.K., Jacob P.C. 1996. Fish fauna of Periyar Tiger Reserve. Journal of the Bombay Natural History Society 93: 35-43.

Received: 22 December 2011 Accepted: 28 February 2012 Published electronically: 31 March 2012 